\title{
Biology and Management of Galinsoga (Galinsoga quadriradiata) in Ornamental Crop Production'
}

Thomas Smith, Chris Marble, Shawn Steed, and Nathan Boyd ${ }^{2}$

\section{Introduction}

Galinsoga (Galinsoga quadriradiata) is an erect (upright), herbaceous, short-lived warm-season annual weed in Florida landscapes, container nurseries, and other agricultural production systems (Figure 1). In nurseries and landscapes, galinsoga can be a troublesome weed, but it has been utilized by some cultures for food or medicinal purposes (Nafici 2016). This article is written for greenindustry professionals and others to aid in the identification and management of galinsoga in and around ornamental plants.

\section{Species Description}

\section{Class}

Dicotyledon

\section{Family}

Asteraceae (Aster family)

\section{Other Common Names}

Peruvian daisy, shaggysoldier, hairy galinsoga

\section{Life Span}

Warm-season annual

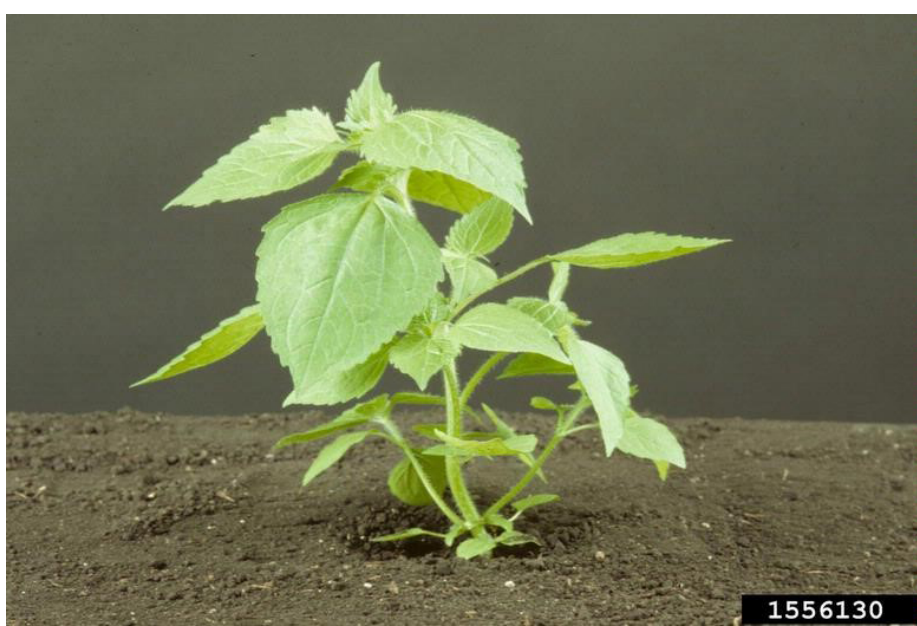

Figure 1. Galinsoga (Galinsoga quadriradiata) growth habit.

Credits: Ohio State Weed Lab, The Ohio State University, Bugwood.org

\section{Habitat}

Galinsoga is a common weed in agricultural fields, container-grown ornamentals, landscape planting beds, lawns, gardens, and other disturbed areas. In container nurseries, galinsoga can be found in containers, in pot drain holes, growing through weed mats, and in noncrop areas around the nursery. In landscapes, it is frequently found growing in turfgrass or in mulched planting beds but is also commonly found in cracks in sidewalks and between patio pavers. Galinsoga has a strong competitive advantage in high-light environments and prefers warm and sunny locations (Damalas 2008).

1. This document is ENH1329, one of a series of the Environmental Horticulture Department, UF/IFAS Extension. Original publication date October 2020. Visit the EDIS website at https://edis.ifas.ufl.edu for the currently supported version of this publication.

2. Thomas Smith, graduate research assistant, Environmental Horticulture Department; Chris Marble, assistant professor, Environmental Horticulture Department, UF/IFAS Mid-Florida Research and Education Center; Shawn Steed, multicounty environmental horticulture Extension agent III; and Nathan Boyd, associate professor, Horticultural Sciences Department, UF/IFAS Gulf Coast REC; UF/IFAS Extension, Gainesville, FL. 


\section{Distribution}

Galinsoga is native to Central and South America. Due to its highly invasive potential, galinsoga has naturalized throughout the Americas, Europe, and Africa and is considered invasive in at least 40 countries (Rajas-Sandoval and Acevedo-Rodriguez 2014). In Florida, galinsoga is found throughout the state, but it is more commonly a nuisance in central and south Florida (Wunderlin et al. 2020).

\section{Growth Habit}

Stems are upright and reach 8 to 32 inches in height. Plants grow and mature quickly and can seed multiple generations per growing season (Rajas-Sandoval and Acevedo-

Rodriguez 2014).

\section{Seedling}

Seedlings are erect with round cotyledons and a multibranched stem. Stems are usually sparsely hairy (Warwick and Sweet 1983) (Figure 2). Seedling germination is highest during the spring and throughout summer and early fall, from March to October. In field soils, germination is common after the soil is disturbed (tillage, planting, etc.), but seeds germinate readily in nursery potting soils. In warmer regions of central and south Florida, germination may occur year-round. Germination can occur between $50^{\circ} \mathrm{F}$ and $95^{\circ} \mathrm{F}$ and tends to increase as light increases, indicating that it readily germinates on the soil surface (Damalas 2008).

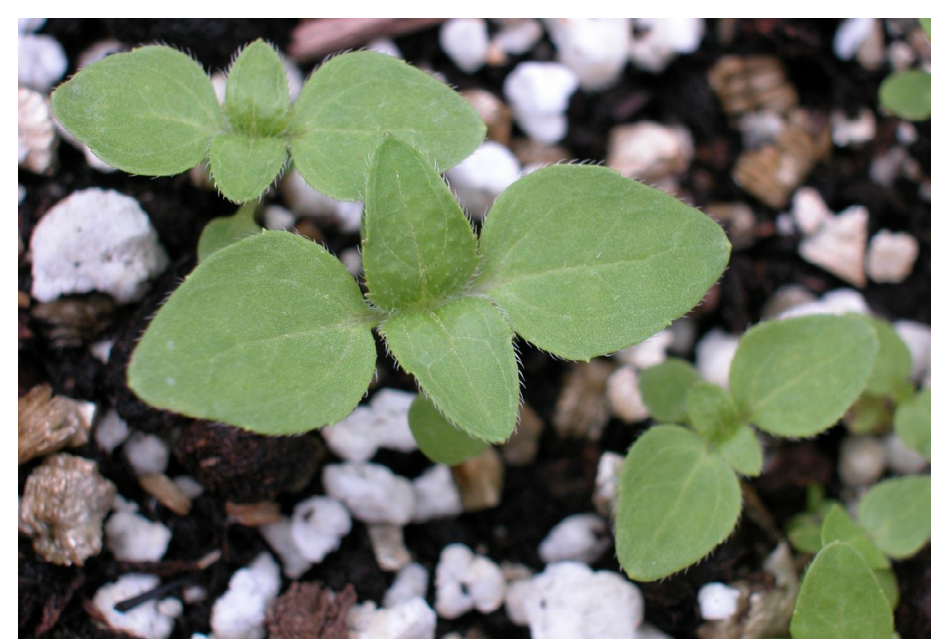

Figure 2. Galinsoga (Galinsoga quadriradiata) seedlings. Credits: Annette Chandler, UF/IFAS

\section{Shoots}

Stems emerge from a shallow, fibrous root system. Leaves are simple, oppositely arranged, and narrow to oblong, and they have a pointed tip (Figure 3). Leaf margins are described as crenulate, meaning that they have small, rounded teeth or serrations. Leafs are 0.4 to 4.3 inches long and 0.2 to 1.6 inches wide (Warwick and Sweet 1983). On the lower region of stems, leaves have a petiole connecting the leafblade and stem. Leaves on the upper regions of the stems, however, are without a petiole (sessile) (RajasSandoval and Acevedo-Rodriguez 2014).

\section{Roots}

Galinsoga has a shallow and somewhat fibrous root system. It does not form rhizomes.

\section{Inflorescence}

The inflorescence, or flower, is typical of plants in Asteraceae (sunflower or daisy family). What is typically described as being a single flower on plants in this family is actually a cluster of many small flowers grouped together in a flower head. In galinsoga, the white "petals" are ray flowers. There are five of these white ray flowers, which have three "teeth" at the tip of the ray. The center of the flower head is yellow and is comprised of many disc flowers. The entire flower head (ray and disc flowers) measures 0.2 to 0.3 inches in diameter, and several hundred flower heads can form on a mature galinsoga plant (Rajas-Sandoval and AcevedoRodriguez 2014; Damalas 2008) (Figure 3).

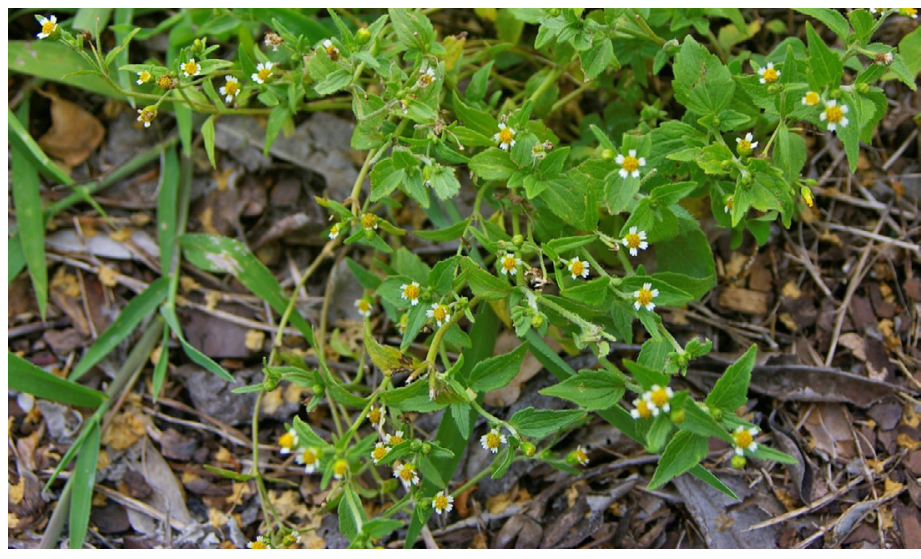

Figure 3. Galinsoga (Galinsoga quadriradiata) shoots. Credits: Annette Chandler, UF/IFAS

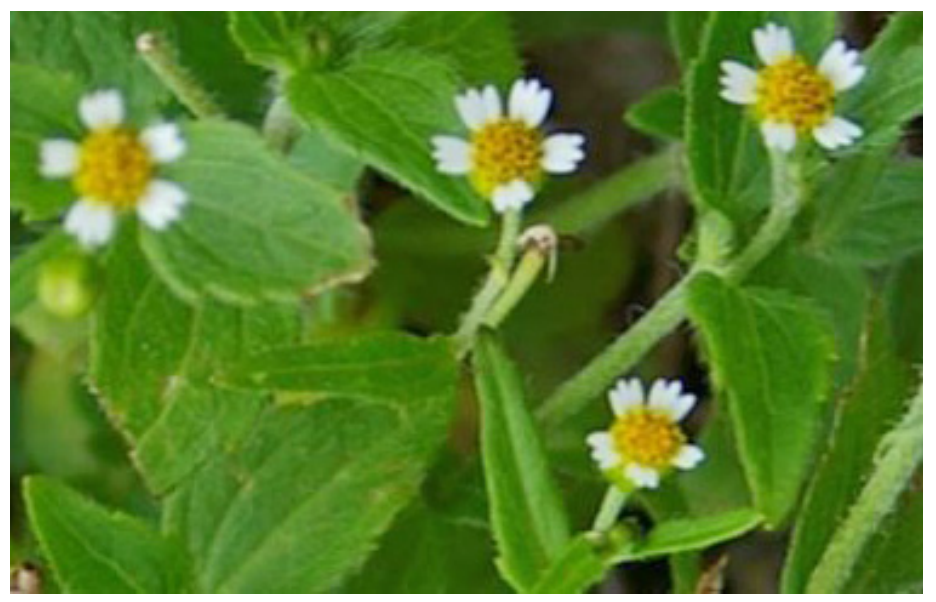

Figure 4. Galinsoga (Galinsoga quadriradiata) flowers. Credits: Annette Chandler, UF/IFAS 


\section{Fruit and Seeds}

Fruit are achenes (dry, one-seeded fruit). Seeds are black and 1 to $1.5 \mathrm{~mm}$ long. Seeds can remain viable for more than 2 years and are the primary mechanism of galinsoga spread. Seeds are easily transported by wind and water (Dalamas 2008).

\section{Similar Species}

While there are 14 species of Galinsoga worldwide (RajasSandoval and Acevedo-Rodriguez 2014), the two most common species of Galinsoga found in nurseries are $G$. quadriradiata and G. parviflora (small-flower galinsoga). Currently, only G. quadriradiata is documented in Florida (Wunderlin 2020). Both species are summer annuals and can be troublesome weeds in landscapes or container ornamentals. The primary difference between the two species is that G. parviflora has fewer hairs (pubescence) on its stems and leaves compared with G. quadriradiata (Dalamas 2008; Warwick and Sweet 1983).

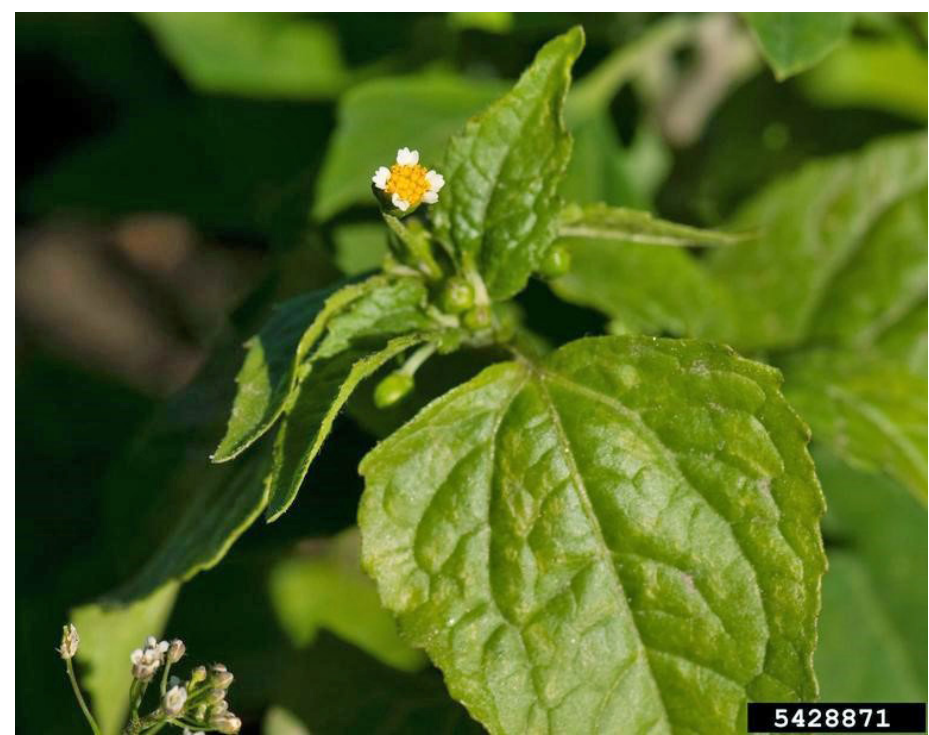

Figure 5. Galinsoga parviflora (small-flower galinsoga) is a closely related species to G. quadriradiata but is often less pubescent (hairy). Credits: Bonsak Hammeraas, The Norwegian Institute of Bioeconomy Research, Bugwood.org

\section{Plant Biology}

Galinsoga is one of the most troublesome weeds of nurseries and landscapes in many parts of the world. It is fast growing and can produce up to 7,500 seeds within only 8 to 9 weeks after germination (Kagima 2000). After seeds mature on the plant, they are immediately viable and can begin to germinate and grow after making contact with the soil, which leads to multiple generations per season (Damalas 2008).

\section{Management \\ Physical and Cultural Control}

Due to limited herbicide options, prevention of weed establishment is the most successful method of management for galinsoga and most other weed species in container nurseries and landscapes. Scout and monitor fields regularly and hand-weed escaped seedlings before flowering occurs. Because galinsoga can regrow after being cut, ensure that roots are removed and plants are not simply clipped during weeding. Research has shown that galinsoga germination is significantly reduced as planting depth increases (Cauwer et al. 2013). Therefore, application of mulch may prevent or reduce establishment and spread. In nursery containers, mulch such as pine bark nuggets, rice hulls, or wood chips can be applied at depths of 1 to 2 inches. In landscapes, pine bark nuggets, pine straw, or other materials can be applied at depths from 2 to 4 inches. Mowing and tillage have not been effective long-term strategies for galinsoga because plants can tolerate mowing, and tillage may increase germination due to soil disturbance (Damalas 2008).

\section{Chemical Control}

Most nonselective postemergence herbicides labeled for use in nurseries and landscapes control galinsoga. In noncrop areas or planting beds, nonselective systemic (translocated) herbicides such as glyphosate can be used. Smaller galinsoga may be controlled by nonselective contact herbicides, such as glufosinate (Finale), diquat (Reward), or pelargonic acid (Scythe), but repeated applications may be needed for larger plants.

Many broad-spectrum preemergence herbicides can be used for galinsoga control. Herbicides such as flumioxazin (Broadstar or SureGuard), dimethenamid-P + pendimethalin (FreeHand), and isoxaben (Gallery) have been shown to be effective for galinsoga control and are labeled for use in nurseries or in landscape planting beds. A complete list of preemergence herbicide options, including the use sites where the herbicides are registered, is included in Table 1.

\section{References}

Cauwer, B. D., R. Devos, S. Claerhout, R. Bulcke, and D. Reheul. 2013. "Seed Dormancy, Germination, Emergence, and Seed Longevity in Galinsoga parviflora and G. quadriradiata." Weed Res. 54:38-47.

Damalas, C. 2008. "Distribution, Biology, and Agricultural Importance of Galinsoga parviflora (Asteraceae).” Weed Biology and Management 8 (3): 147-153. https://doi. org/10.1111/j.1445-6664.2008.00290.x 
Kagima, D. 2000. "Bibliography and Biology of Galinsoga spp." Ames, IA: The ISU Weed Biology Library, Iowa State University.

Nafici, S. 2016. "Weed of the Month: Galinsoga." Urban Gardening and Ecology Garden News Blog. Brooklyn Botanical Gardens. Accessed 18 Feb. 2020. https://www. bbg.org/news/weed_of_the_month_galinsoga

Rojas-Sandoval, J., and P. Acevedo-Rodriguez. 2014. "Galinsoga quadriradiata (Shaggy Soldier) Datasheet." CAB International. Accessed 16 Mar. 2020. https://www.cabi.org/ isc/datasheet/120145

USDA, NRCS. 2020. The PLANTS Database. Accessed 20 Feb. 2020. https://plants.usda.gov/core/ profile? symbol=GAPA2

Warwick, S., and R. Sweet. 1983. "The Biology of Canadian Weeds. 58. Galinsoga parviflora and G. quadriradiata." Canadian Journal of Plant Science 63:695-709. Accessed 18 Feb. 2020. https://doi.org/10.4141/cjps83-087

Wunderlin, R. P., B. F. Hansen, R. Franck, and F. B. Essig. 2020. "Atlas of Florida Plants." Accessed 4 Mar. 2020. http:// florida.plantatlas.usf.edu 
Table 1. Preemergence herbicides labeled for use in nursery production and landscape planting beds for the control of galinsoga. This table lists registered pesticides that should be integrated with other pest management methods. Additional information on integrated pest management methods can be requested from UF/IFAS Extension horticulture or agriculture agents. A list of local UF/IFAS Extension offices is available at https://sfyl.ifas.ufl.edu/find-your-local-office/.

\begin{tabular}{|c|c|c|c|c|c|c|c|c|}
\hline Active ingredient & $\begin{array}{l}\text { Example } \\
\text { trade name/ } \\
\text { formulation }\end{array}$ & $\begin{array}{c}\text { Rate per } \\
\text { acre } \\
\text { (lb ai/acre) }^{1}\end{array}$ & $\begin{array}{c}\text { WSSA } \\
\text { Herbicide } \\
\text { Group }^{2}\end{array}$ & Efficacy $^{3}$ & $\begin{array}{l}\text { Container } \\
\text { production }\end{array}$ & $\begin{array}{c}\text { Field } \\
\text { production }\end{array}$ & $\begin{array}{c}\text { Greenhouses/ } \\
\text { fully enclosed } \\
\text { structures }\end{array}$ & Landscape \\
\hline \multirow[t]{2}{*}{ pendimethalin } & Pendulum $^{\circledast} 2 \mathrm{G}$ & $200 \mathrm{lb}(4)$ & \multirow[t]{2}{*}{3} & \multirow[t]{2}{*}{ P-S } & YES & YES & NO & YES \\
\hline & Pendulum $^{\circledast} 3.3 \mathrm{EC}$ & $4.8 \mathrm{pt}(2)$ & & & YES & YES & NO & YES \\
\hline prodiamine & Barricade $^{\circledast} 4 \mathrm{FL}$ & $48 \mathrm{fl} \mathrm{oz} \mathrm{(1.5)}$ & 3 & $\mathrm{~S}$ & YES & YES & NO & YES \\
\hline \multirow[t]{2}{*}{ flumioxazin } & Broadstar $^{\mathrm{TM}} 0.25 \mathrm{G}$ & $150 \mathrm{lb}(0.375)$ & \multirow[t]{2}{*}{14} & \multirow[t]{2}{*}{$\mathrm{C}$} & YES & YES & NO & YES \\
\hline & SureGuard $^{\circledR} 4 \mathrm{SC}$ & $\begin{array}{l}12 \mathrm{fl} \mathrm{oz} \\
(0.375)\end{array}$ & & & $\mathrm{YES}^{4}$ & $\mathrm{YES}^{4}$ & YES $^{5}$ & YES $^{6}$ \\
\hline oxadiazon & Ronstar $^{\circledast} 2 \mathrm{G}$ & $200 \mathrm{lb}(4)$ & 14 & $\mathrm{~S}$ & YES & YES & NO & YES \\
\hline dimethenamid-p & Tower $^{\circledast}$ 6EC & $32 \mathrm{fl} \mathrm{oz} \mathrm{(1.5)}$ & 15 & $\mathrm{~S}-\mathrm{C}$ & YES & YES & NO & YES \\
\hline s-metolachlor & $\begin{array}{l}\text { Pennant Magnum }{ }^{\circledast} \\
7.6 \mathrm{EC}\end{array}$ & $2.6 \mathrm{pt}(2.5)$ & 15 & $C$ & YES & YES & NO & YES \\
\hline isoxaben & Gallery ${ }^{\circledast} 4.16 \mathrm{SC}$ & $31 \mathrm{fl} \mathrm{oz} \mathrm{(1)}$ & 21 & $\mathrm{~S}-\mathrm{C}$ & YES & YES & NO & YES \\
\hline $\begin{array}{l}\text { pendimethalin + } \\
\text { dimethenamid-p }\end{array}$ & FreeHand $^{\circledast} 1.75 \mathrm{G}$ & $\begin{array}{c}200 \mathrm{lb}(2+ \\
1.5)\end{array}$ & $3+15$ & $C$ & YES & YES & NO & YES \\
\hline $\begin{array}{l}\text { trifluralin + } \\
\text { isoxaben }\end{array}$ & Snapshot $^{\circledast} 2.5 \mathrm{TG}$ & $200 \mathrm{lb}(4+1)$ & $3+21$ & $\mathrm{~S}-\mathrm{C}$ & YES & YES & NO & YES \\
\hline $\begin{array}{l}\text { prodiamine + } \\
\text { isoxaben }\end{array}$ & Gemini $^{\mathrm{TM}} 3.7 \mathrm{SC}$ & $\begin{array}{c}87 \mathrm{fl} \mathrm{oz} \mathrm{(1.5} \\
+1)\end{array}$ & $3+21$ & $\mathrm{C}$ & YES & YES & NO & NO \\
\hline \multicolumn{9}{|c|}{$\begin{array}{l}1 \text { Rates of herbicide product are listed and active ingredient applied at that rate are shown parenthetically. Rates shown are generally the } \\
\text { highest recommended label rate for a single application. Check product labels for further details. } \\
{ }^{2} \text { Herbicide groups are based according to primary sites of action and can be used to select herbicides that have differing sites of action (Weed } \\
\text { Technology 17:605-619 [2003]) to minimize the potential for the development of herbicide-resistant weeds. } \\
{ }^{3} \mathrm{P}=\text { poor control; } \mathrm{S}=\text { suppression, } \mathrm{C}=\text { good control based on product labels or experimental data evaluating the highest recommended label } \\
\text { rate. } \\
{ }^{4} \mathrm{Can} \text { only be used in selected conifer and deciduous tree species. Check manufacturer's label for a complete list of species and recommended } \\
\text { application methods. } \\
{ }^{5} \text { Can be applied if no ornamentals are present. Plants can be placed back inside the greenhouse } 24 \text { hr after application and after product has } \\
\text { been watered in. } \\
{ }^{6} \text { Can be applied as a directed application around established woody landscape ornamentals. }\end{array}$} \\
\hline
\end{tabular}

